\title{
Beyond politics: additional factors underlying skepticism of a COVID-19 vaccine
}

\author{
Kenneth Boyd ${ }^{1}$ D
}

Received: 4 December 2020 / Accepted: 15 January 2021 / Published online: 27 January 2021 (C) Springer Nature Switzerland AG 2021

\begin{abstract}
Even before it had been developed there had already been skepticism among the general public concerning a vaccine for COVID-19. What are the factors that drive this skepticism? While much has been said about how political differences are at play, in this article I draw attention to two additional factors that have not received as much attention: witnessing the fallibility of the scientific process play out in real time, and a perceived breakdown of the distinction between experts and non-experts.
\end{abstract}

Keywords Vaccine skepticism · Trust in experts · Fallibility

A recent survey conducted by The Policy Institute of King's College reported that nearly 1 in 6 people surveyed in the United Kingdom would refuse an eventual COVID-19 vaccine (The Policy Institute 2020), while in the US surveys have indicated that the number might be twice as high, with more than 1 in 3 saying that they would refuse a vaccine (O'Keefe 2020). Skepticism with regards to the safety of vaccines is not new; however, given the urgency of getting the global pandemic under control, it is important to consider why it is that reported levels of refusal to be vaccinated are so high, and what can potentially be done about it.

Although there is no single factor that can fully explain skepticism surrounding the COVID-19 vaccine, many news and science communication outlets (especially in the US) have focused on political factors. For instance, data suggest that the politically conservative are much more likely than the politically liberal to state that they would refuse a vaccine, are more likely to state that they believe that the pandemic

\section{Kenneth Boyd}

kenneth.boyd@gmail.com

1 Department for the Study of Culture, University of Southern Denmark, Campusvej 55,

5230 Odense, Denmark 
is not a significant problem, and are more likely to believe in conspiracy theories about the origin of the virus and the proposed responses to it (Newport 2020). While political affiliation is no doubt one factor that correlates with vaccine skepticism, reports of refusals to accept a COVID-19 vaccine are found at all points along the political spectrum, and thus there are other factors that need to be considered. Here I draw attention to two additional such factors.

The first pertains to potential misconceptions about the nature of the scientific process. Recent philosophical and sociological work has demonstrated a number of ways in which the general public's perception of science can be inaccurate, in that people tend to conceive of the scientific enterprise as one that involves a progressive march towards objective truth, free from the influence of personal values (see for instance Collins and Pinch 2008; Douglas 2009; Oreskes 2019). One reason for these misconceptions may stem from unfamiliarity: members of the general public are often not privy to the details of ongoing scientific investigations, but are instead presented with the results thereof. For instance, despite the existence of skepticism in some portions of the population, there is broad scientific consensus that vaccines such as the widely employed MMR vaccine is safe and effective (Deer 2011). Parents today who are deciding whether to vaccinate their children are thus able to receive a definitive answer from doctors and other experts as to what the best course of action is. While there are always additional questions and avenues of exploration, parents today are, for all intents and purposes, witnessing the outputs of the successful conclusion of a scientific process.

This is very much not the case when it comes to the ongoing development of a COVID-19 vaccine: instead, people have been witnessing the scientific process play out in real time. Part of this experience has involved witnessing how such a process is inherently fallible. For instance, there has been a significant amount of back-and-forth with regards to the efficacy of wearing face masks in preventing the spread of the virus, with different governments mandating different orders at various times. This indecisiveness does not represent a failure on the part of scientists, but is instead reflective of the nature of scientific progress as involving the ongoing acquisition of evidence and revision of hypotheses. However, with the public having been exposed to a tremendous amount of information about COVID-19, precautionary measures, and daily updates about the development of a vaccine, the fallible nature of scientific progress is on full display. With fallibility comes opportunity for skepticism: the developments in theories, changes in views, and occasionally conflicting advice could be interpreted as a reason to distrust scientists, rather than the natural progression of a fallible process. Indeed, a number of authors have shown how indicators of fallibility can adversely affect the level of the public's trust in science: for instance, Oppenheimer et al. (2019) note how mere disagreement among experts can work to undermine public confidence in the relevant science. While disagreements are to be expected in scientific discourse, those regarding the development of the COVID-19 vaccine have been plentiful and public, something that may result in a much more significant lowering of confidence among the public.

A second factor contributing to skepticism surrounding the COVID-19 vaccine pertains to a perceived breakdown of the distinction between expert and non-expert: with so much information available to anyone at any time, members of the general 
public may perceive themselves as being capable of becoming well-informed on their own, and may thus reject being categorized as a "non-expert". While it is doubtless the case that there are important differences between scientific experts and members of the general public (Collins 2014), the perceived breakdown between these groups may have consequences for the receptivity of the general public to receiving advice from the experts.

For example, in response to many Americans refusing to wear masks and engage in proper social distancing, Dr. Anthony Fauci stated that while he admired their "independent spirit", that it was now time for them to "do what you're told" (Farr 2020). It is understandable why he made this statement: it would be better, after all, if members of the public did listen to the experts. At the same time, however, there is reason to worry that telling someone that they simply need to do as they are told could backfire, resulting in the public trusting the scientific experts less. This is not simply because one's independent spirit might also make one intentionally defiant; rather, simply being presented information as something to uncritically accept may be interpreted as a marker of untrustworthiness. For instance, Neil Levy (2019) considers the problem of why presenting a skeptic with the fact that a certain view is the consensus in the scientific community is unlikely to change their mind: presenting information in this way can be interpreted as a lack of empathy on the part of the provider as it does not show engagement with the concerns and beliefs of the recipient. Perceiving the experts as being no better informed than oneself will likely exacerbate this problem: individuals may feel as though they ought to be participants in dialogue as opposed to mere recipients of imperatives.

These factors thus create a tension when thinking about the best way to communicate important information about the COVID-19 vaccine to the general public: while it is seemingly important that individuals have this information, providing it as it becomes available risks increasing skepticism insofar as it reports the results from an ongoing, fallible process of scientific discovery, and can result in non-experts falsely being under the impression that they are as well-informed as the experts, and thus being less receptive to being told what to do. While there is not, I think, an easy way to resolve this tension, it is nevertheless worth paying attention to, given that it is predicated upon factors that can result in skepticism irrespective of one's political orientation.

\section{References}

Collins, H. (2014). Are we all scientific experts now? Cambridge: Wiley.

Collins, H., \& Pinch, T. (2008). Dr. Golem: How to think about medicine. Chicago: University of Chicago Press.

Deer, B. (2011). How the case against the MMR vaccine was fixed. BMJ, 342(7788), 77-82. https://doi. org/10.1136/bmj.c5347.

Douglas, H. (2009). Science, policy, and the value-free ideal. Pittsburgh: University of Pittsburgh Press.

Farr, C. (2020). Fauci says U.S. has 'independent spirit,' but now is the time to 'do what you're told'. CNBC. https://www.cnbc.com/2020/11/12/fauci-says-us-has-independent-spirit-but-now-is-thetime-to-do-what-youre-told.html.

Levy, N. (2019). Due deference to denialism: Explaining ordinary people's rejection of established scientific findings. Synthese, 196, 313-327. 
Newport, F. (2020). The partisan gap in views of the coronavirus. Gallup. https://news.gallup.com/opini on/polling-matters/311087/partisan-gap-views-coronavirus.aspx.

O'Keefe, S. M. (2020). One in three Americans would not get COVID-19 vaccine. Gallup. https://news. gallup.com/poll/317018/one-three-americans-not-covid-vaccine.aspx.

Oppenheimer, M., Oreskes, N., Jamieson, D., Brysse, K., O’Reilly, J., Shindell, M., \& Wazeck, M. (2019). Discerning experts: The practices of scientific assessment for environmental policy. Chicago: University of Chicago Press.

Oreskes, N. (2019). Why trust science? Princeton: Princeton University Press.

The Policy Institute. (2020). Who's least likely to say they'll get a Covid-19 vaccine? The Policy Institute News Centre. https://www.kcl.ac.uk/news/whos-least-likely-to-say-theyll-get-a-covid-19-vaccine.

Publisher's Note Springer Nature remains neutral with regard to jurisdictional claims in published maps and institutional affiliations. 